09

\title{
Усиление фотолюминесценции квантовых точек CdSe/CdS на кварцевых подложках с наночастицами серебра
}

\author{
(C) Р.Р. Шамилов, ${ }^{1}$ В.И. Нуждин, ${ }^{2}$ В.Ф. Валеев, ${ }^{2}$ Ю.Г. Галяметдинов, ${ }^{1,2}$ А.Л. Степанов ${ }^{1,2}$ \\ ${ }^{1}$ Казанский национальный исследовательский технологический университет, \\ 420015 Казань, Россия \\ ${ }^{2}$ Казанский фризико-технический институт им. Е.К. Завойского Казанского научного центра РАН, \\ 420029 Казань, Россия \\ e-mail: reedish@mail.ru
}

(Поступило в Редакцию 17 мая 2015 г.

В окончательной редакции 31 марта 2016 г.)

Получены многослойные системы, состоящие из слоя гибридных квантовых точек структуры ядро/оболочка $\mathrm{CdSe} / \mathrm{CdS}$, химически-синтезированных и нанесенных на поверхность кварцевого стекла, содержащего в приповерхностной области ионно-синтезированные наночастицы серебра. Наночастицы серебра характеризуются оптическим поглощением вследствие проявления локализованного поверхностного плазмонного резонанса. Проведено наблюдение изменения интенсивности фотолюминесценции слоя с квантовыми точками в зависимости от его удаления от поверхности стекла с металлическими наночастицами. Обнаружено повышение интенсивности фотолюминесценции квантовых точек при ее возбуждении в спектральной области плазмонного поглощения наночастиц серебра. Определено оптимальное расстояние между слоями для максимального проявления эффекта усиления фотолюминесценции квантовых точек в ближнем поле металлических наночастиц.

\section{Введение}

Полупроводниковые наночастицы - квантовые точки (KT или QD) на основе халькогенидов кадмия в течение последних десятилетий интенсивно исследуются в связи с их уникальными размерно-зависимыми оптическими свойствами. Эффективная фотолюминесценция во всем диапазоне видимого света таких КТ позволяет найти им множество применений в различных областях, таких как светоизлучающие устройства, солнечные батареи, люминесцентные метки и т.д. [1].

В последнее время широко развивается наноплазмоника - область знаний, изучающая различные оптические эффекты, возникающие за счет возбуждения плазмонов - коллективных колебаний электронов проводимости в металлах [2]. Одно из проявлений плазмонов заключается в их влиянии на оптические характеристики различных люминофоров, в том числе и КТ, расположенных вблизи металлов, в частности, металлических наночастиц $(\mathrm{MH})$, в которых возникает локализованный поверхностный плазмонный резонанс (ППР). Наиболее сильно ППР в видимом диапазоне света выражен для наночастиц благородных металлов [3].

Возникающие локальные электромагнитные поля повышенной интенсивности в результате ППР вблизи МН могут значительно усилить интенсивность излучения КТ. Например, в работе [4] было продемонстрировано увеличение интенсивности люминесценции гибридных КТ ядро/оболочка $\mathrm{CdSe} / \mathrm{ZnS}$ до 15 раз в ближнем поле у поверхности наноостровковых пленок серебра. Поэтому на практике структуры с МН, характеризуемые ППР, могут быть использованы для повышения свечения сред с КТ.
С другой стороны, в системах МН-КТ может происходить понижение интенсивности или полное тушение люминесценции КТ в результате безызлучательного переноса энергии возбуждения от КТ к МН в случае малого расстояния между ними [5]. Данные особенности в поведение свечения могут оказаться полезными для использования МН-КТ систем в качестве высокочувствительных оптических химических и биологических сенсоров $[6,7]$.

Таким образом, в общем случае характер влияния МН на интенсивность люминесценции КТ определяется совокупностью факторов, таких как расстояние между МН и КТ, их размером, формой, типом химического вещества, длиной волны возбуждаемого света и т.д. [8-10].

Существуют различные подходы получения МН, такие как химическое осаждение, вакуумное напыление и др., среди которых наиболее интересным представляется метод ионной имплантации. Данный метод позволяет получать композиционные материалы на основе различных диэлектрических матриц (силикатные стекла, полимеры, кристаллы) в приповерхностном имплантированном тонком слое, в котором синтезируются МН определенного размера [11]. Структуры с МН, синтезированными ионной имплантацией, могут быть использованы для повышения эффективности люминесценции различных материалов. Так, в работе [12] был продемонстрирован эффект усиления люминесценции пленок $\mathrm{ZnO}$, нанесенных на поверхность кварца, содержащих ионносинтезированные наночастицы серебра.

В настоящей работе поставлена задача по конструированию системы, организованной комбинацией из слоя наночастиц серебра, полученного ионной имплантацией в приповерхностной области кварцевого стекла, и тонкой пленки из гибридных КТ ядро/оболочка $\mathrm{CdSe} / \mathrm{CdS}$, 
химически-синтезированных и нанесенных на поверхность стекла, а также проведение исследования влияния ППР эффектов МН на фотолюминесценцию КТ.

\section{1. Методика эксперимента}

KT CdSe и $\mathrm{CdSe} / \mathrm{CdS}$ получены по коллоидному методу синтеза в водно-органических средах. К раствору $0.72 \mathrm{~g} \mathrm{NaOH} \mathrm{в} 2 \mathrm{ml}$ бидистиллированной воды при постоянном перемешивании и при температуре $90^{\circ} \mathrm{C}$ добавлялось последовательно $30 \mathrm{ml}$ глицерина и $10 \mathrm{ml}$ олеиновой кислоты. Далее в смесь вводилось $266 \mathrm{mg}$ $(1 \mathrm{mmol})$ ацетата кадмия дигидрат, растворенного в $2 \mathrm{ml}$ бидистиллированной воды, после которого реакционная смесь нагревалась до $190^{\circ} \mathrm{C}$. При этой температуре вводилось $5 \mathrm{ml} 0.5 \mathrm{M}$ (1 mmol) раствора селеносульфата натрия, полученного кипячением до полного растворения $10 \mathrm{mmol}$ порошкообразного селена в $50 \mathrm{ml}$ раствора, содержащего $40 \mathrm{mmol}$ сульфита натрия, для образования наночастиц. Далее реакционную смесь перемешивали при $190^{\circ} \mathrm{C}$ в течение $15 \mathrm{~min}$, после чего смесь охладили до комнатной температуры. Для полной очистки синтезированные KT CdSe 3 раза переосаждали этанолом с последующим диспергированием их в н-гексане.

Гибридные КТ ядро/оболочка $\mathrm{CdSe} / \mathrm{CdS}$ получены в водно-этанольной среде, содержащей $1 \mathrm{mmol}$ ацетата кадмия дигидрат и ядра KT CdSe, к которым вводился $0.2 \mathrm{M}$ раствор тиоацетамида $(1 \mathrm{mmol})$ при температуре $50^{\circ} \mathrm{C}$. Далее наночастицы $\mathrm{CdSe} / \mathrm{CdS}$ были очищены переосаждением.

Плазмонные структуры на основе кварцевого стекла $\left(\mathrm{SiO}_{2}\right)$ с наночастицами серебра были изготовлены методом низкоэнергетической высокодозовой ионной имплантации. Имплантация проводилась однозарядными ионами $\mathrm{Ag}^{+}$с энергией $30 \mathrm{keV}$, дозой $4 \cdot 10^{16} \mathrm{ion} / \mathrm{cm}^{2}$ при плотности тока в ионном пучке $8 \mu \mathrm{A} / \mathrm{cm}^{2}$ на ускорителе ИЛУ-3 по методике, подробно описанной в работе [13]. Морфология поверхностей, имплантированных $\mathrm{SiO}_{2}$, получена с помощью сканирующего зондового микроскопа Ntegra Aura Probe Nanolaboratory фирмы NT-MDT, работающего в режиме атомно-силовой микроскопии (ACM) в полуконтактной моде (tapping mode).

Спектры излучения и возбуждения фотолюминесценции наночастиц регистрировались на спектрофлуориметре Cary Eclipse (Varian). Спектры оптического поглощения были получены на сканирующем двулучевом спектрометре Perkin Elmer Instrumental LAMBDA 35 UV/VIS. Размеры КT были оценены на просвечивающем электронном микроскопе (ПЭМ) Hitachi HM-7700 при $100 \mathrm{keV}$ и методом динамического светорассеяния (ДРС) на установке Malvern Zetasizer Nano, оснащенной узким светофильтром с центром пропускания при $632.8 \mathrm{~nm}$.

Тонкие пленки КТ были осаждены на Spincoater Laurell WS-650-23 из раствора КT $\mathrm{CdSe} / \mathrm{CdS}$ в нгексане на поверхности кварцевых стекол и кварцевых стекол с наночастицами серебра. Толщина слоя пленок
КТ для всех образцов была одинаковой и оценивалась величиной примерно $35 \mathrm{~nm}$.

В ряде случаев для создания буферного слоя между поверхностью с МН и слоем с КТ на кварцевые стекла наносились разделительные слои полиметилметакрилата (ПММА) разной толщины нанесением раствора полимера (молекулярная масса - 110000 D) разных концентраций $(2.5-25 \mathrm{mg} / \mathrm{ml})$. Толщина слоя ПММА контролировалась методом ступеньки на конфокальном лазерном оптическом микроскопе Olympus LEXT OLS4000. Толщины более тонких слоев ПММА, чем $100 \mathrm{~nm}$, определялись экстраполяцией по зависимости толщины, определяемой на микроскопе, от концентрации раствора ПММА.

\section{2. Результаты и обсуждение}

Водно-органический метод синтеза позволяет получить KT CdSe, характеризуемые интенсивной люминесценцией в видимом диапазоне спектра [14]. Использование в данном методе олеиновой кислоты в качестве стабилизатора позволяет диспергировать КТ в различных неполярных растворителях. При этом длина волны излучения зависит от размера КТ, образование которых в свою очередь контролируются временем и температурой синтеза. Ранее полученные по данной методике KT CdSe со средним размером $2.5 \mathrm{~nm}$ при температуре синтеза $70^{\circ} \mathrm{C}$ демонстрируют узкополосную люминесценцию с максимумом на длине волны $513 \mathrm{~nm}$ [15]. Увеличение температуры синтеза до $190^{\circ} \mathrm{C}$ приводит к увеличению размера KT CdSe до $5 \mathrm{~nm}$, а максимум люминесценции при этом оказывается при $612 \mathrm{~nm}$. Как пример, на рис. 1 приведено ПЭМ-изображение КТ, синтезированных при повышенной температуре.

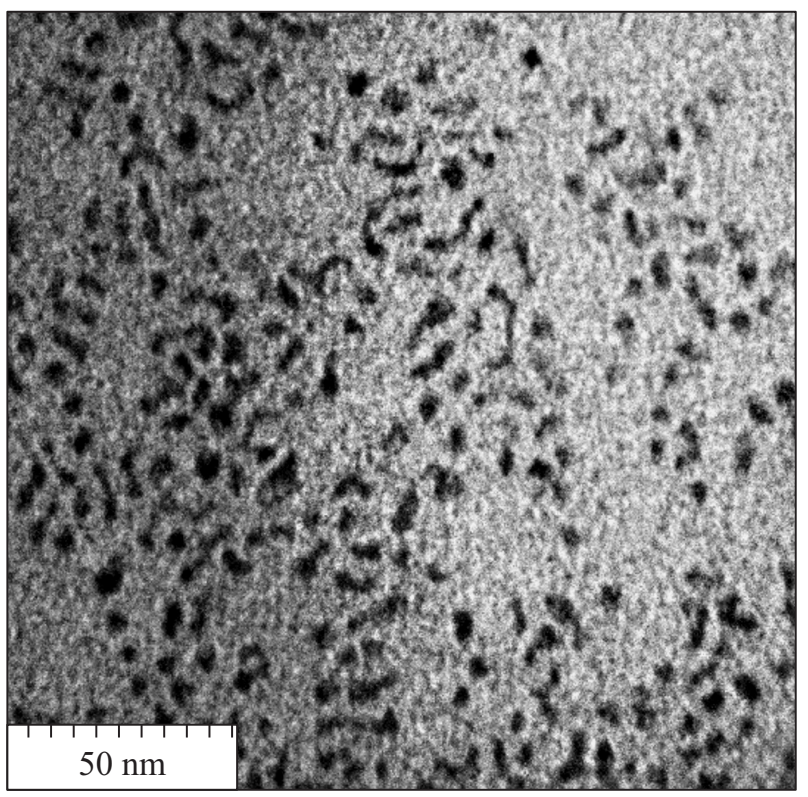

Рис. 1. ПЭМ-изображение КT CdSe (темные области), синтезированных при $190^{\circ} \mathrm{C}$. 
С целью повышения эффективности свечения люминесценции на KT CdSe, используемых в качестве ядра, наращивалась оболочка из $\mathrm{CdS}$ с формированием частиц гибридной структуры типа ядро-оболочка [16]. Такой подход к синтезу КТ позволил существенно повысить интегральную интенсивность люминесценции гибридных KT по сравнению с KT CdSe при одинаковой оптической плотности растворов с частицами на длине волны $350 \mathrm{~nm}$ (рис. 2,a). Данный эффект объясняется снижением поверхностных дефектов на поверхности ядер $\mathrm{CdSe}$ после заращивания их оболочкой. Согласно данным ДРС, средний размер гибридных частиц $\mathrm{CdSe} / \mathrm{CdS}$ с учетом молекул стабилизатора на поверхности КТ составил $9 \mathrm{~nm}$ (рис. 2,b).

В настоящей работе КT $\mathrm{CdSe} / \mathrm{CdS}$ были использованы для формирования слоя, который наносился на поверхность кварцевого стекла, содержащего ионносинтезированные наночастицы серебра. В свою очередь, АCМ-изображение поверхности кварцевого стекла с МH до осаждения КТ приведен на рис. 3, $a$. Наблюдаемые на поверхности полусферические образования соответствуют частично оголенным над имплантированным слоем стекла наночастицам серебра [17].

Характер влияния наночастиц серебра на оптические свойства $\mathrm{KT} \mathrm{CdSe} / \mathrm{CdS}$ в слоевой структуре изучался
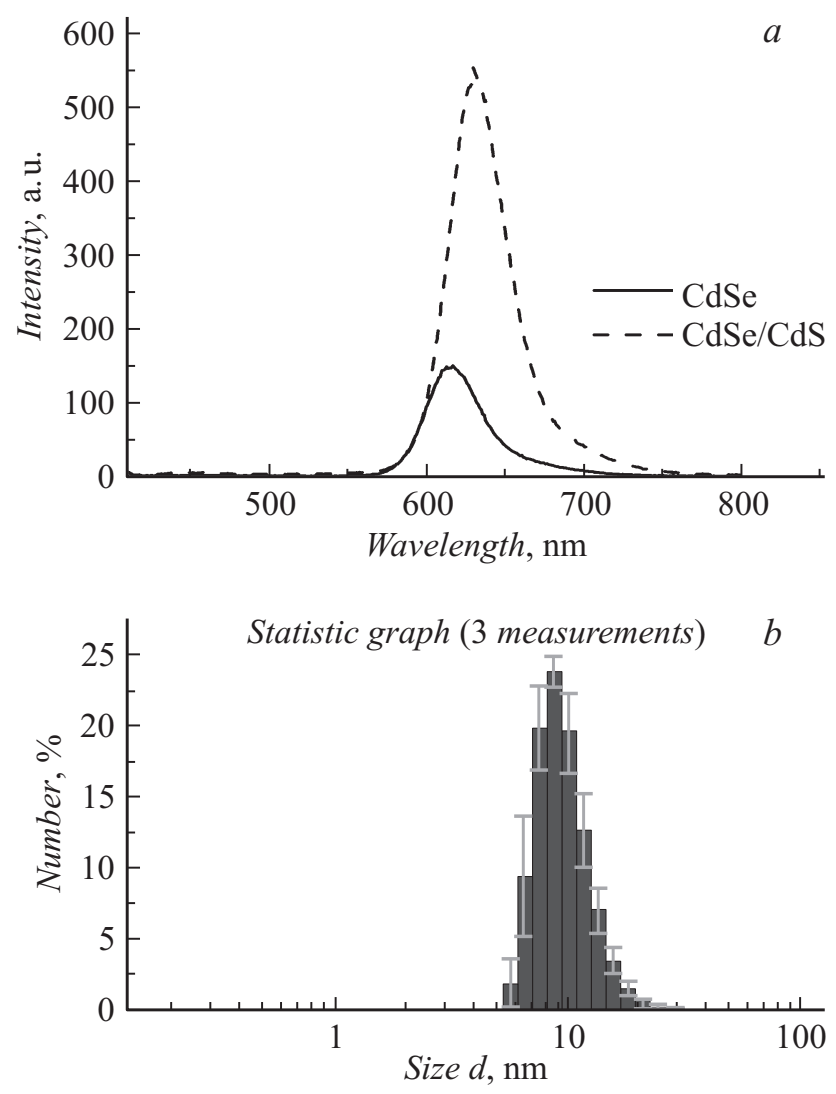

Mean with +/-1 standard deviation error bar

Рис. 2. $a-$ спектры фотолюминесценции КТ CdSe и $\mathrm{CdSe} / \mathrm{CdS}$ в н-гексане при возбуждении на длине волны $350 \mathrm{~nm}$, $b$ - распределение KT CdSe/CdS по размерам.
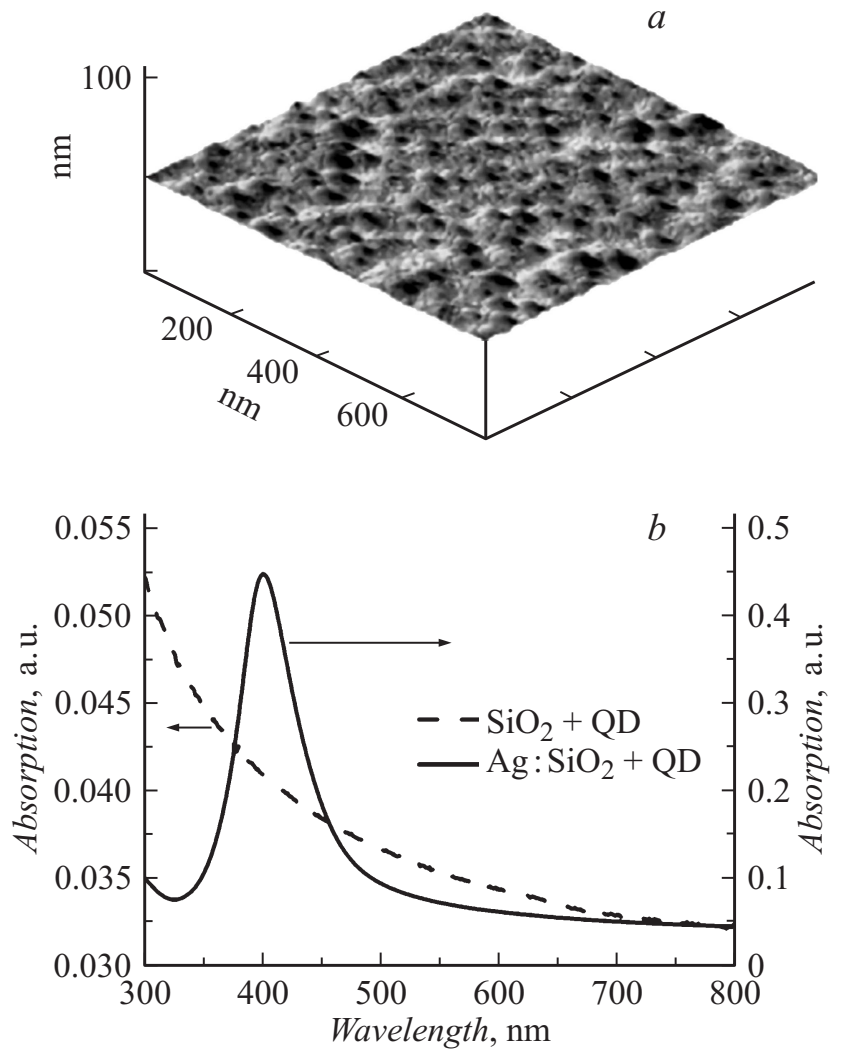

Рис. 3. $a-\mathrm{ACM} \mathrm{изображение} \mathrm{образца} \mathrm{кварцевой} \mathrm{подложки} \mathrm{с}$ наночастицами серебра, $b-$ спектры поглощения изучаемых образцов.

в сравнении с контрольными образцами слоев КТ той же толщины $(\sim 35 \mathrm{~nm})$, нанесенных на поверхность неимплантированного кварцевого стекла. На рис. 3, $b$ представлены спектры поглощения контрольного образца $\left(\mathrm{SiO}_{2}+\mathrm{KT}\right)$ и исследуемого образца $\left(\mathrm{Ag}: \mathrm{SiO}_{2}+\mathrm{KT}\right)$, состоящего из суперпозиции вкладов от поглощения наночастиц серебра и слоя КТ. Как видно, в последнем спектре присутствует широкая селективная полоса с максимумом при $400 \mathrm{~nm}$, обусловленная ППР поглощением в наночастицах серебра [11].

Для обнаружения влияния ППР МН на люминесценцию КТ сопоставим люминесценцию образцов $\mathrm{SiO}_{2}+\mathrm{KT}$ и $\mathrm{Ag}: \mathrm{SiO}_{2}+\mathrm{KT}$, возбуждаемую на длине волны $400 \mathrm{~nm}$ в спектральной области ППР поглощения (рис. 4). Как видно из рисунка, интенсивность полосы люминесценции с максимумом вблизи $640 \mathrm{~nm}$ слоя КТ в образце с наночастицами серебра оказывается заметно ниже, чем в контрольном образце. Наблюдаемое гашение люминесценции, очевидно, обусловлено безызлучательными переходами и передачи энергии от КТ к МН, возникающими в случае близкого их взаиморасположения или полного контакта, как это предполагается в работах для различных люминесцирующих веществ $[5,18]$.

Вследствие малости размеров наночастиц серебра, поглощение ими света сосредоточено в коротковолновой области спектра (рис. $3, b$ ). Поэтому поглощение 


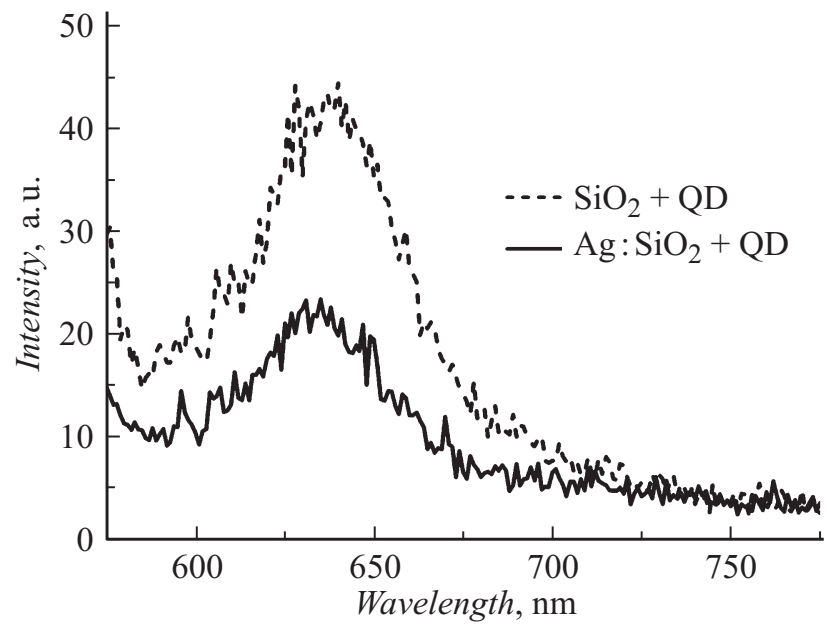

Рис. 4. Спектры люминесценции слоя с КТ, осажденного на $\mathrm{SiO}_{2}$ и $\mathrm{Ag}: \mathrm{SiO}_{2}$, при возбуждении на длине волны $400 \mathrm{~nm}$.

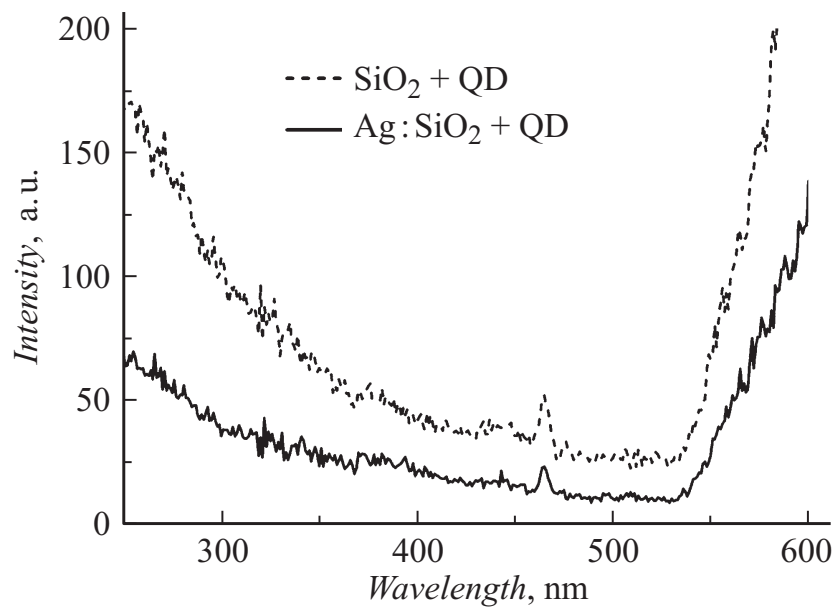

Рис. 5. Спектры возбуждения люминесценции КТ в образцах $\mathrm{SiO}_{2}+$ КТ и $\mathrm{Ag}: \mathrm{SiO}_{2}+\mathrm{KT}$.

МН излучения КТ пренебрежимо мало и ожидать существенного понижения интенсивности люминесценции образцов не приходится.

Спектры возбуждения люминесценции КТ контрольного и исследуемого $\mathrm{Ag}: \mathrm{SiO}_{2}+\mathrm{KT}$ образцов приведены на рис. 5. По приведенным спектрам можно заключить, что для образца $\mathrm{Ag}: \mathrm{SiO}_{2}+\mathrm{KT}$ гашение люминесценции, подобно наблюдаемому на рис. 4, будет происходить также и для свечения, возбуждаемого в широком интервале длин волн от 200 до $600 \mathrm{~nm}$ (рис. 5).

Для предотвращения тушения люминесценции КТ в среде с МН, в литературе [19-21] предлагается использовать органические или неорганические разделительные слои между частицами, с целью увеличения расстояния между ними и предотвращения обмена энергией между КТ и МН. Толщина разделительного слоя варьируется в каждом конкретном типе композиционной системы. При этом разделительный слой должен быть достаточно тонким, чтобы обеспечить нахождение КТ в ближнем поле ППР МН для возможного усиления люминесценции КТ.

Поэтому в настоящей работе для предотвращения тушения люминесценции КТ были сформированы образцы, в которых между слоем из КТ и поверхностью кварцевого стекла с наночастицами серебра помещался дополнительный тонкий разделительный слой. В качестве разделительного слоя использовались пленки ПММА различной толщины, полученные из растворов разных концентраций. Для определения эффективной толщины разделительного слоя и исследования влияния ППР эффектов МН на свечение КТ были проведены сравнительные измерения люминесценции КТ для образцов с прослойками из ПММА.

Для всех образцов $\mathrm{Ag}: \mathrm{SiO}_{2}+$ ПММА + КТ с разделительным слоем из ПММА наблюдалась люминесценция, возбуждаемая на длине волны $400 \mathrm{~nm}$, как и в случае рис. 4. Зависимость изменения интенсивности излучения КТ на длине волны $640 \mathrm{~nm}$, выражаемая в виде фактора люминесценции (PL factor), определяемого отношением интенсивности излучения в исследуемом образце к контрольному от толщины разделительного слоя ПММА, приведена на рис. 6. Значение фактора люминесценции меньше единицы соответствует тушению люминесценции, а больше единицы - его усилению.

Как было показано на рис. 4, в отсутствие разделительного слоя наблюдается тушение люминесценции КТ. Введение наиболее тонкого слоя ПММА с толщиной $\sim 37 \mathrm{~nm}$ в структуру образца ведет к снижению степени тушения свечения КТ (рис. 6). Как следует из приведенной зависимости, с последующим утолщением разделительного слоя ПММА тушение люминесценции сменяется ее возгоранием. Максимальное усиление люминесценции зафиксировано для пленки ПММА толщиной порядка $150 \mathrm{~nm}$ (рис. 6). При дальнейшем увеличении разделительного слоя происходит монотонное снижение фактора усиления люминесценции, и наличие слоя с

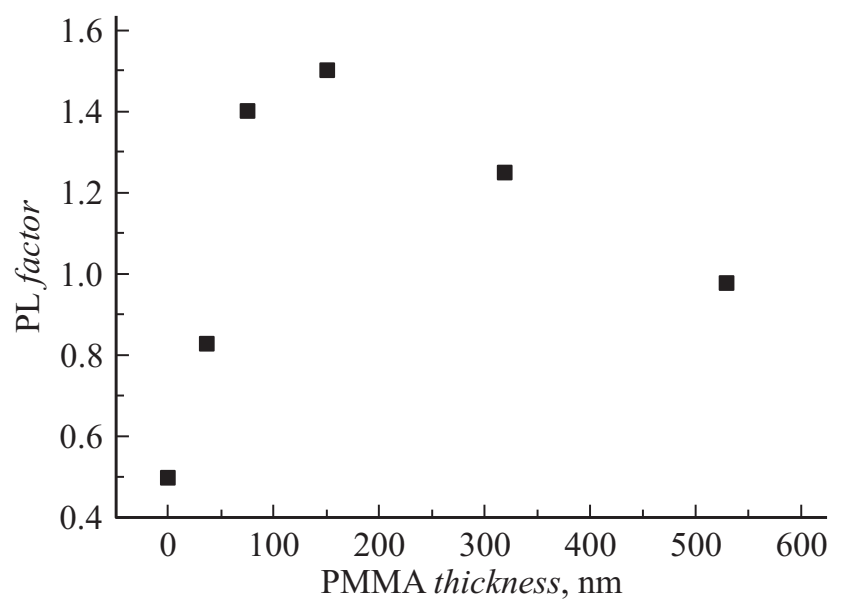

Рис. 6. Зависимость отношения интенсивностей люминесценции (PL factor) KT на длине волны $640 \mathrm{~nm}$ исследуемого образца к контрольному от толщины разделительного слоя ПММА. Длина воны возбуждения люминесценции $400 \mathrm{~nm}$. 


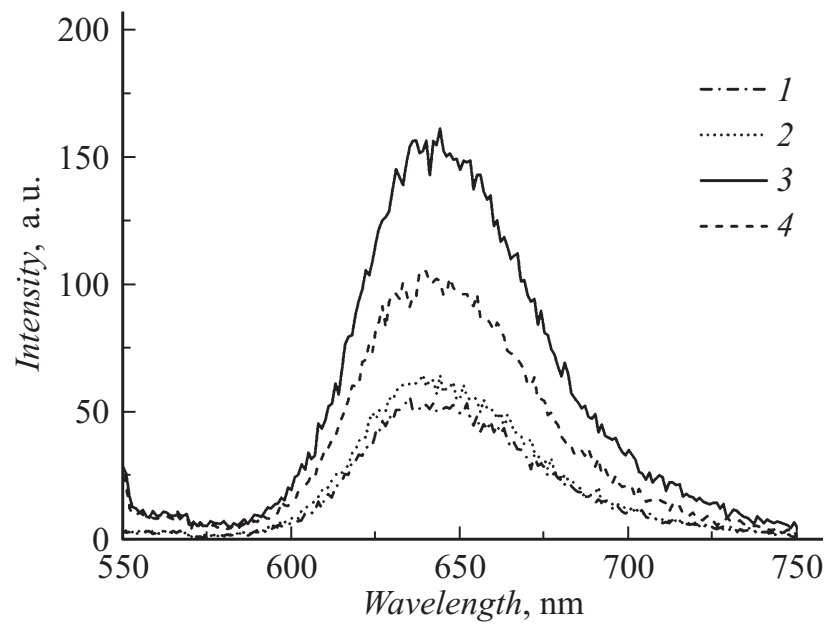

Рис. 7. Спектры люминесценции образца $\mathrm{Ag}: \mathrm{SiO}_{2}+$ ПММА + КТ $(1,3)$ и контрольного образца $(2,4)$ с толщиной разделительного слоя $150 \mathrm{~nm}$ при возбуждении на длинах волн $350(1,2)$ и $400 \mathrm{~nm}(3,4)$.

наночастицами серебра в образце на интенсивность свечения КТ перестает сказываться.

Для примера, на рис. 7 приведены спектры люминесценции КТ для образца $\mathrm{Ag}: \mathrm{SiO}_{2}+$ ПММА + КТ с толщиной разделительного слоя $150 \mathrm{~nm}$ в сравнении с контрольным образцом $\mathrm{SiO}_{2}+\mathrm{KT}$ при возбуждении свечения на длине волны $400 \mathrm{~nm}$, т. е. вблизи максимума ППР поглощения наночастиц серебра. На приведенных спектрах отчетливо видно усиление интенсивности КТ в максимуме полосы фотолюминесценции на длине волны $640 \mathrm{~nm}$ до $50 \%$.

Дополнительно на рис. 7 приведены спектральные зависимости люминесценции КТ для тех же образцов, но при возбуждении на длине волны $350 \mathrm{~nm}$ в спектральной области в стороне от ППР поглощения МН. В данном случае в противоположность усилению люминесценции наблюдается небольшее ее тушение.

Известно, что собственная люминесценция КT CdSe и $\mathrm{CdSe} / \mathrm{CdS}$ (рис. 2,a) обусловлена возбуждением экситонов падающим на образец электромагнитным полем и последующей их рекомбинацией [22]. При этом эффективность люминесценции определяется разностью между излучательными и безызлучательными затуханиями. В общем случае в системе КТ-МН проявляются два конкурирующих процесса $[2,18]$. Это безызлучательный перенос энергии от КТ к МН, и он возможен только на малых расстояниях между ними. Противоположным эффектом является усиление люминесценции КТ, располагающихся в ближнем локальном поле ППР МН. Это поле экспоненциально спадает от поверхности МН. Таким образом, в зависимости от расстояния между КТ и МН может происходить доминирование в суперпозиции одного из вкладов (процессов) или их взаимная компенсация.

В настоящей работе оба эти явления наблюдаются при изменении расстояния слоя КТ от поверхности кварце- вого стекла с наночастицами серебра. Так, в отсутствии разделительного слоя наблюдается тушение люминесценции КТ (рис. 4). Несмотря на то что КТ располагаются максимально близко к МН, т. е. при наиболее сильном ППР-поле, степень эффективности безызлучательного переноса энергии оказывается существенно выше вклада от ППР в усиление люминесценции.

При увеличении разделительного слоя до определенной толщины между КТ и МН отчетливо наблюдается усиление люминесценции КТ (рис. 6 и 7). В этом случае можно предполагать, что эффективность процесса безызлучательного переноса энергии с расстоянием от МН спадает существенно быстрее, чем ближнее ППР поле. И в результате наблюдается усиление люминесценции КТ вследствие влияния на них плазмонного поля МН. Очевидно, что с удалением КТ от МН данное поле экспоненциально спадает и усиления люминесценции не происходит (рис. 6).

Отметим, что усиление люминесценции КТ наблюдается только при ее возбуждении в спектральной области ППР-поглощения наночастиц серебра. Очевидно, что ближнее ППР-поле формируется на длинах волн ППР-поглощения МН [3], и именно при возбуждении люминесценции КТ в этом спектральном диапазоне должно происходить ее усиление. Подтверждением данному обстоятельству является спектральная зависимость возбуждения люминесценции КТ в образце $\mathrm{Ag}: \mathrm{SiO}_{2}+$ ПММА + КТ, спектры свечения которого приведены на рис. 8. На рисунке видно, что в спектре возбуждения люминесценции в образце $\mathrm{Ag}: \mathrm{SiO}_{2}+$ ПММА + КТ присутствует селективная полоса, совпадающая по спектральному положению и положению максимума с полосой ППР-поглощения наночастиц серебра. Подобная селективная полоса возбуждения люминесценции КТ не наблюдается в спектре контрольного образца без МН.

В свою очередь эффект усиления возбуждения КТ может распространяться в значительных расстояниях

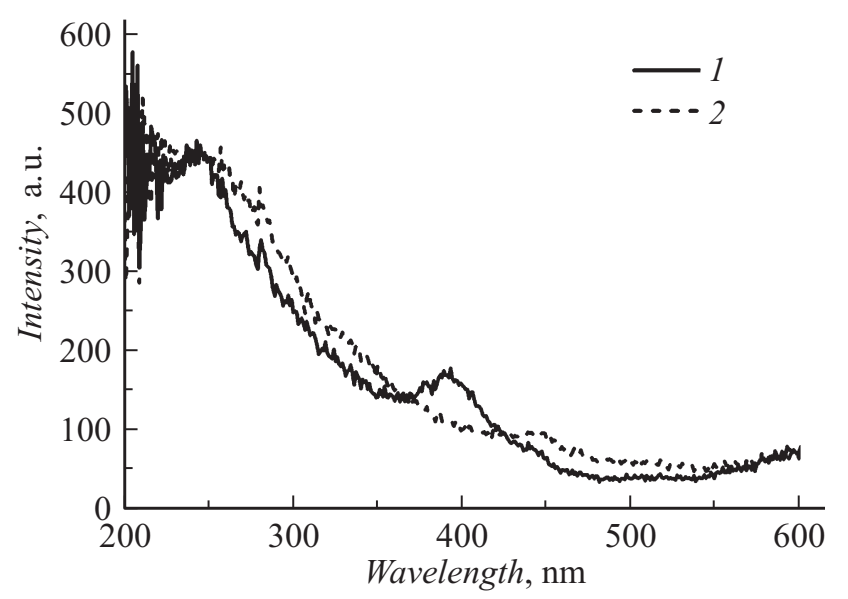

Рис. 8. Спектры возбуждения люминесценции КТ исследуемого (1) и контрольного (2) образцов, соответствующие излучению на длине волны $640 \mathrm{~nm}$ (рис. 7), при толщине разделительного слоя из ПММА $150 \mathrm{~nm}$. 
от поверхности МН [20] с постепенным уменьшением интенсивности КТ по мере удаления от наночастиц серебра. Так, увеличение слоя ПММА до $530 \mathrm{~nm}$ привело к полному исчезновению эффекта влияния плазмонов на люминесценцию КТ (рис. 6).

\section{3. Заключение}

Представлены оригинальные методы синтеза КT CdSe и ядро/оболочка $\mathrm{CdSe} / \mathrm{CdS}$ в водно-спиртовых средах, отличающиеся своей экологичностью и доступностью. Сформированы многослойные системы, состоящие из слоя гибридных КТ структур ядро/оболочка $\mathrm{CdSe} / \mathrm{CdS}$, химически-синтезированных и нанесенных на поверхность кварцевого стекла, содержащего в приповерхностной области ионно-синтезированные наночастицы серебра, проявляющие ППР-поглощение. Исследованы особенности свечения КТ, располагающихся в ближнем ППР-поле МН. Обнаружено тушение или усиление фотолюминесценции КТ при ее возбуждении в спектральной области ППР-поглощения наночастиц серебра в зависимости от расстояния между КТ и МН.

Работа выполнена при финансовой поддержке гранта РНФ № 14-13-00758.

\section{Список литературы}

[1] Sun K., Vasudev M., Jung H.S., Yang J., Kar A., Li Y., Reinhardt K., Snee P., Stroscio M.A., Dutta M. // Microelectronics J. 2009. Vol. 40. N 3. P. 644-649.

[2] Климов В.В. Наноплазмоника М.: Физматлит, 2009. 480 с.

[3] Kreibig U., Vollmer M. Optical properties of metal clusters. Springer Series in Materials Science. Vol. 25. Springer, Berlin, 1995.

[4] Soganci I.M., Nizamoglu S., Mutlugun E., Akin O. Demir H.V. // Opt. Express. 2007. Vol. 15. N 22. P. 14 289-14298.

[5] Pons T., Medintz I.L., Sapsford K.E., Higashiya S., Grimes A.F., English D.S., Mattoussi H. // Nano Lett. 2007. Vol. 7. N 10. P. 3157-3164.

[6] Zhang M., Cao X., Li H., Guan F. Guo J., Shen F., Luo Y., Sun C., Zhang L. // Food Chemistry. 2012. Vol. 135. P. $1894-1900$.

[7] Wang L., Zhang J., Bai H., Li X., Lv P., Guo A. // Appl. Biochem. Biotechnol. 2014. Vol. 173. N 5. P. 1073-1082.

[8] Haldar K.K., Sen T., Mandal S., Patra A. // Chem. Phys. Chem. 2012. Vol. 13. P. 3989-3996.

[9] Zhang X., Marocico C.A., Lunz M., Gerard V.A. Gun'ko Y.K., Lesnyak V., Gaponik N., Susha A.S., Rogach A.L., Bradley A.L. // ACS Nano. 2012. Vol. 6. N 10. P. 9283-9290.

[10] Ito Y., Matsuda K., Kanemitsu Y. // Phys. Rev. B. 2007. Vol. 75. P. 033309.

[11] Степанов А.Л. Фотонные среды с наночастицами, синтезированными ионной имплантацией. Саарбрюккен: Lambert Acad. Publ., 2014.

[12] Xiao X.H., Ren F., Zhou X.D., Peng T.C., Wu W., Peng X.N., Yu X.F., Jiang C.Z. // App. Phys. Lett. 2010. Vol. 97. P. 071909.
[13] Степанов А.Л., Валеев В.Ф., Нуждин В.И., Базаров В.Ф. // ЖТФ. 2009. Т. 79. Вып. 10. С. 102-107.

[14] Liu L., Peng Q., Li Y. // Inorg. Chem. 2008. Vol. 47. N 11. P. 5022-5028.

[15] Shukla R.K., Galyametdinov Yu.G., Shamilov R.R., Haase W. // Liquid Crystals. 2014. Vol. 41. N 12. P. 1889-1896.

[16] Chaudhuri R.G., Paria S. // Chem. Rev. 2012. Vol. 112. N 4. P. 2373-2433.

[17] Stepanov A.L., Popok V.N. // Surf. Sci. 2004. Vol. 566-568. P. $1250-1254$.

[18] Maйер C.A. Плазмоника: теория и приложения. М.Ижевск: НИЦ Регулярная и хаотическая динамика, 2011. $204 \mathrm{c}$.

[19] Chen Y.C., Munechika K., Plante I.J., Munro A.M., Skrabalak S.E., Xia Y., Ginger D.S. // Appl. Phys. Lett. 2008. Vol. 93. P. 053106.

[20] Seo J., Fudala R., Kim W.-J., Rich R., Tabibi B., Cho H., Gryczynski Z., Gryczynski I., Yu W. // Optic. Mater. Express. 2012. Vol. 2. N 8. P. 1026-1039.

[21] Liu B., Liao T., Tseng S., Lee M. // Appl. Surface Sci. 2014. Vol. 292. P. 615-619.

[22] Гапоненко С.В., Розанов Н.Н., Ивченко Е.Л., Федоров А.В., Бонч-Бруевич А.М., Вартанян Т.А., Пржсибельский С.Г. Оптика наноструктур / Под ред. А.В. Федорова СПб.: Недра, 2005. 326 с. 